\title{
Comparison of growth, protein and carotenoid contents of some freshwater microalgae and the effects of urea and cultivation in a photobioreactor with reflective broth circulation guide on Desmodesmus subspicatus LC172266
}

\author{
Chijioke Nwoye Eze $e^{1,2,4} \cdot$ Innocent Okonkwo Ogbonna ${ }^{3} \cdot$ Hideki Aoyagi $^{2} \cdot J^{\prime a m e s}$ Chukwuma Ogbonna ${ }^{1}$ (i)
}

Received: 19 October 2020 / Revised: 6 March 2021 / Accepted: 9 June 2021 / Published online: 18 June 2021

(c) Associação Brasileira de Engenharia Química 2021

\begin{abstract}
This study assessed the potential of enhancing carotenoids and protein accumulation by Desmodesmus subspicatus LC172266 by urea supplementation and cultivation in a novel flat plate air-lift photobioreactor with broth circulation guides. Addition of $0.2 \mathrm{~g} \mathrm{~L}^{-1}$ urea to BG11 medium significantly increased the cell growth in both flask and photobioreactor cultures. Carotenoid accumulation by $D$. subspicatus was about 5.7 times $\left(15.5 \pm 0.1 \mathrm{mgg} \mathrm{cell}^{-1}\right)$ higher in the photobioreactor with reflective broth circulation guide than in the flask culture $\left(2.3 \pm 0.1 \mathrm{mgg}^{-1}\right.$ cell $)$ and about $46 \%$ higher than the carotenoid content obtained in the photobioreactor without broth circulation guide (control). The cell growth rate was about 2 times higher in the photobioreactor with reflective broth circulation guide $\left(0.41 \pm 0.005\right.$ day $\left.^{-1}\right)$ than in flask culture $\left(0.20\right.$ day $\left.^{-1}\right)$, and in the control photobioreactor $\left(0.28\right.$ day $\left.^{-1}\right)$. Both the protein contents and biomass concentrations were significantly enhanced by cultivation in the novel photobioreactor. This research has demonstrated that the flat plate air-lift photobioreactor installed with reflective broth circulation guide substantially enhanced carotenoid production by D. subspicatus LC172266.
\end{abstract}

Keywords Biomass production $\cdot$ Nitrogen source $\cdot$ Mass transfer in photobioreactors $\cdot$ Pigments $\cdot$ Microalgae $\cdot$ Light distribution in photobioreactors

\section{Introduction}

The increased global demand for carotenoids due to increased awareness of their multidimensional bioactivities (Sathasivam and Ki 2018), biological roles in humans and animals (Sing et al. 2019) and wide applications in various industries (Cezare-Gomes et al. 2019) can be met with microalgae sources. While the demand for the synthetic sources has decreased due to safety and

James Chukwuma Ogbonna

james.ogbonna@unn.edu.ng

1 Department of Microbiology, University of Nigeria, Nsukka, Nigeria

2 Department of Life and Environmental Sciences, University of Tsukuba, Tsukuba, Japan

3 Department of Microbiology, Federal University of Agriculture, Makurdi, Nigeria

4 Present Address: Department of Science Laboratory Technology, University of Nigeria, Nsukka, Nigeria environmental concerns (Koyande et al. 2019), most of the natural sources of carotenoids such as plants and animals (Koyande et al. 2019) have many limitations (Cardoso et al. 2017). For instance, production of carotenoids by land plants is considered unsustainable due to low productivity (low content and the long time taken for the plants to mature), and the indirect effects on food security due to competition for arable land and other agricultural inputs. In the case of animals, the productivities are too low to compete with other sources (Cardoso et al. 2017). Microorganisms are considered the best alternative sources of carotenoids due to some obvious reasons which include (i) high carotenoid contents in many strains, (ii) easy with which the culture conditions can be optimized for high productivity, (iii) high growth rates, and thus high productivities, and (iv) low cost of substrates (Cardoso et al. 2017; Mussagy et al. 2018). Amongst the microorganisms, microalgae can store large quantities of carotenoids produced from their active carotenogenic pathway (Sing et al. 2019) as against yeast and bacteria. Protein is another 
important product of microalgae used as food/feed supplements. The protein content of microalgae varies from 30 to $70 \%$ of dry weight depending on the species of microalgae as well as the culture conditions (Ejike et al. 2017; Dolganyuk et al. 2020). The concentration of nitrogen in the nutrient medium is known to affect protein accumulation in microalgae species. For instance, Xie et al. (2017) reported an increase in protein content of Chlorella vulgaris to $44.3 \%$ under optimized culture condition.

Although microalgae are known to be good sources of these and other useful metabolites, efficient growth and production of useful metabolites by microalgae require efficient but cheap photobioreactors. Currently, both open air and closed photobioreactors are used for cultivation of various species of microalgae (Cezare-Gomes et al. 2019). It is relatively cheap to construct and maintain open air photobioreactors but they give lower productivities while the problem of contamination limits their application to species with selective growth conditions such as Spirulina (alkali), Duneliella (high salinity), and Chlorella (very high growth rates). In comparison with open air photobioreactors, construction and maintenance of closed photobioreactors are expensive but they can be used to cultivate any species of microalgae without the problem of contamination. They are therefore suitable for production of low-volume high-value products such as carotenoids without contamination for application in the pharmaceutical, cosmetic and food industries (CezareGomes et al. 2019). However, there is a need to reduce the costs of microalgae production in closed photobioreactors by designing novel and efficient close photobioreactors with high mass transfer and good light distribution (Pal et al. 2019; Eida et al. 2018).

Efficient mass cultivation of microalgae in photobioreactors for production of useful metabolites largely dependent on three factors; 1 . Selection of species with high productivity (Novoveska et al. 2019); 2. Use of efficient photobioreactors to enhance growth rates and productivities (Huang et al. 2017); and 3. Manipulation of cultivation conditions, which currently involves the use of stressed conditions as widely reported in literature (Koyande et al. 2019; Mussagy et al. 2018; Novoveska et al. 2019; Panahi et al. 2019). In terms of selection of species/strains for production of pigments, few microalgae species which include but not limited to Dunaliella sp., Porphydrium sp., and Spirulina sp. have been reported widely (Koyande et al. 2019). However, these species grow under selective growth conditions such as high $\mathrm{pH}$ or high salinity. Reports on the use of freshwater microalgae such as Desmodesmus sp. for production of carotenoids have been very scanty (Pozzobon et al. 2020). According to Neofotis et al (2016), Desmodesmus genus is still in obscurity even though many strains within the genus may be resourceful for bioactive molecule production. There is therefore a need to explore the potentials of this freshwater alga.
Among the various closed photobioreactors, the advantages of flat plate photobioreactors have been highlighted (Cezare-Gomes et al. 2019; Huang et al. 2017). We have developed a novel flat plate air-lift photobioreactor with broth circulation guides, and showed that it was very effective in enhancing microalgae growth and lipid accumulation (Eze et al. 2017). The present study was aimed at evaluating the effectiveness of the photobioreactor in enhancing accumulation of other bioproducts such as cell biomass, protein, and carotenoid byour new isolate, Desmodesmus subspicatus LC172266. The results showed that this strain has great potentials for carotenoid and protein production and that production of these bioproducts was enhanced by supplementing the BG 11 with urea and using reflective broth circulation guide to enhance mass transfer and light distribution inside the photobioreactor.

\section{Materials and methods}

\section{Microalgae identification}

The microalgae species maintained in the Department of Microbiology, University of Nigeria, Nsukka were used. Their generic names were based on morphological identification (Ogbonna and Ogbonna 2015). They were further identified based on their total DNA as reported by Eze et al. (2017). Construction of the phylogenetic trees and bootstrap analysis were done according to Saitou and Nei (1987) and Felsenstein (1985), respectively.

\section{Inoculum preparation}

The microalgae were sub-cultured in BG-11 medium while each inoculum was prepared by inoculating $10 \%$ of the culture into $200 \mathrm{~mL}$ of the BG11 medium in a $500 \mathrm{~mL}$ Erlenmeyer flask. It was cultivated on an orbital shaker under continuous illumination. The light intensity was $50 \mu \mathrm{mol}$ photons $\mathrm{m}^{-2} \mathrm{~s}^{-1}$ while rotation speed was $100 \mathrm{rpm}$. The cultivation was done at $30^{\circ} \mathrm{C}$ (which was the optimum temperature as determined in a preliminary experiment and used in our previous studies (Ogbonna and Ogbonna 2015; Eze et al. 2017) for 10 days.

\section{Microalgae cultivation}

\section{Flask cultivation}

The composition of the $\mathrm{BG} 11$ was (in $\mathrm{gL}^{-1}$ ): $\mathrm{NaNO}_{3}, 0.25$; $\mathrm{K}_{2} \mathrm{HPO}_{4}, 0.04 ; \mathrm{MgSO}_{4} \cdot 7 \mathrm{H}_{2} \mathrm{O}, 0.075 ; \mathrm{CaCl}_{2} \cdot 2 \mathrm{H}_{2} \mathrm{O}, 0.027$; $\mathrm{C}_{6} \mathrm{H}_{8} \mathrm{O}_{7}, 0.006 ; \mathrm{C}_{6} \mathrm{H}_{8} \mathrm{O}_{7} . \mathrm{nFe} . \mathrm{nNH}_{3}, 0.006$; EDTA, 0.001; $\mathrm{NaCO}_{3}, 0.02$; and $1.0 \mathrm{~mL}$ A5 + Costock solution. The composition of the $\mathrm{A} 5+$ Co stock solution was distilled water, 
$1.0 \mathrm{~L} ; \mathrm{H}_{3} \mathrm{BO}_{3}, 2.860 \mathrm{~g} ; \mathrm{ZnSO}_{4} \cdot 7 \mathrm{H}_{2} \mathrm{O}, 0.222 \mathrm{~g} ; \mathrm{MnCl}_{2} \cdot 4 \mathrm{H}_{2} \mathrm{O}$, $1.81 \mathrm{~g} ; \mathrm{CuSO}_{4} \cdot 5 \mathrm{H}_{2} \mathrm{O}, 0.079 \mathrm{~g} ; \mathrm{Na}_{2} \mathrm{MoO}_{4} \cdot 2 \mathrm{H}_{2} \mathrm{O}, 0.390 \mathrm{~g}$ and $\mathrm{Co}\left(\mathrm{NO}_{3}\right)_{2} \cdot 6 \mathrm{H}_{2} 0,0.0494 \mathrm{~g}$. The medium was dispensed (200 mL each) into $500 \mathrm{~mL}$ Erlenmeyer flasks after adjusting the $\mathrm{pH}$ to 7.2 using $0.1 \mathrm{~N} \mathrm{HCl}$ and $\mathrm{NaOH}$. The flasks were plugged with foam corks and then sterilized for $15 \mathrm{~min}$ at $121^{\circ} \mathrm{C}$. The seed culture $(10 \%)$ was inoculated in the sterile growth medium in four replicates and cultivated at $30{ }^{\circ} \mathrm{C}$ on a rotary shaker at the speed of $100 \mathrm{rpm}$ under $50 \mu \mathrm{mol} . \mathrm{m}^{-2} \mathrm{~s}^{-1}$ continuous light illuminations for 8 days. The microalgae culture broth $(5.0 \mathrm{~mL})$ was sampled at 2-day intervals to measure the cell concentrations and carotenoid contents. At the end of the 8 days, the dry cell weights were determined by centrifuging broth samples $(5.0 \mathrm{~mL}$ each $)$ at $5000 \mathrm{rpm}$ for $5 \mathrm{~min}$, drying the cell pellet in an oven at $70^{\circ} \mathrm{C}$ for $24 \mathrm{~h}$ and weighing. The dried cell biomass was also used for protein content determination.

Urea nitrogen supplementation Urea was optimized in $200 \mathrm{~mL}$ of BG11 medium (pH7.2) containing $5.0 \mathrm{gL}^{-1}$ of glucose and either $0.1,0.2,0.5$ or $1.0 \mathrm{gL}^{-1}$ of urea in $500 \mathrm{~mL}$ Erlenmeyer flasks. The algal cultures were replicated four times and seeded with the $10 \%$ inoculum. The microalgae cultures were incubated and sampled as described in Sect. 2.3.1 to measure the cell growth and carotenoid contents.

\section{Cultivation in the Photobioreactor}

Detailed description of the photobioreactor (Fig. 1) has been given in our previous paper (Eze et al. 2017). The photobioreactor was washed and dried inside the clean bench under $\mathrm{UV}$ irradiation for $24 \mathrm{~h}$. The BG 11 medium was prepared as described in Sect. 2.3.1 without organic carbon source, supplemented with $0.2 \mathrm{gL}^{-1}$ urea and the $\mathrm{pH}$ adjusted to 7.2. Sterilization was done for $15 \mathrm{~min}$ at a temperature of $121^{\circ} \mathrm{C}$. The photobioreactor without broth circulation guide served as the control while the effects of installation of three types of circulation guides (transparent, opaque and reflective) were investigated. The angle of inclination of the guides was $75^{\circ}$ and aluminum foil was used to wrap the photobioreactor around so that illumination was only from the top (Eze et al. 2017). The working and inoculum volumes were $2.70 \mathrm{~L}$ and $300 \mathrm{~mL}$, respectively. The photobioreactor was illuminated from the top by six white fluorescent lamps. The light intensity at the surface of the culture was $100 \mu$ mol photons $\mathrm{m}^{-2} \mathrm{~s}^{-1}$. The aeration gas was a mixture of air and carbon dioxide gas in a ratio of 20:1 $\left(\mathrm{CO}_{2}\right.$ concentration $=5 \%$ ) and the flow rate was $1.5 \mathrm{~L} \mathrm{~min}^{-1}$. The culture temperature was monitored manually with the aid of a laboratory thermometer inserted in the culture through a small opening from the top of PBR. The cultivation was done for 7 days in three replicates but sampling was done every day. The $\mathrm{pH}$ of the culture was monitored daily by measuring the $\mathrm{pH}$ of the sampled culture with the aid of digital $\mathrm{pH}$ meter. The biomass, carotenoid and protein concentrations were determined as described below.

\section{Analytical methods}

\section{Cell growth rate}

The cell (biomass) concentrations were measured by the optical density $\left(\mathrm{OD}_{680}\right)$ using a UV/VIS spectrophotometer (GENESYS 10S UV-Vis, Thermo Fisher Scientific, MA, USA). The biomass concentrations during the cultivation
Fig. 1 A schematic diagram of the novel air-lift flat plate photobioreactor installed with an inclined broth circulation guide

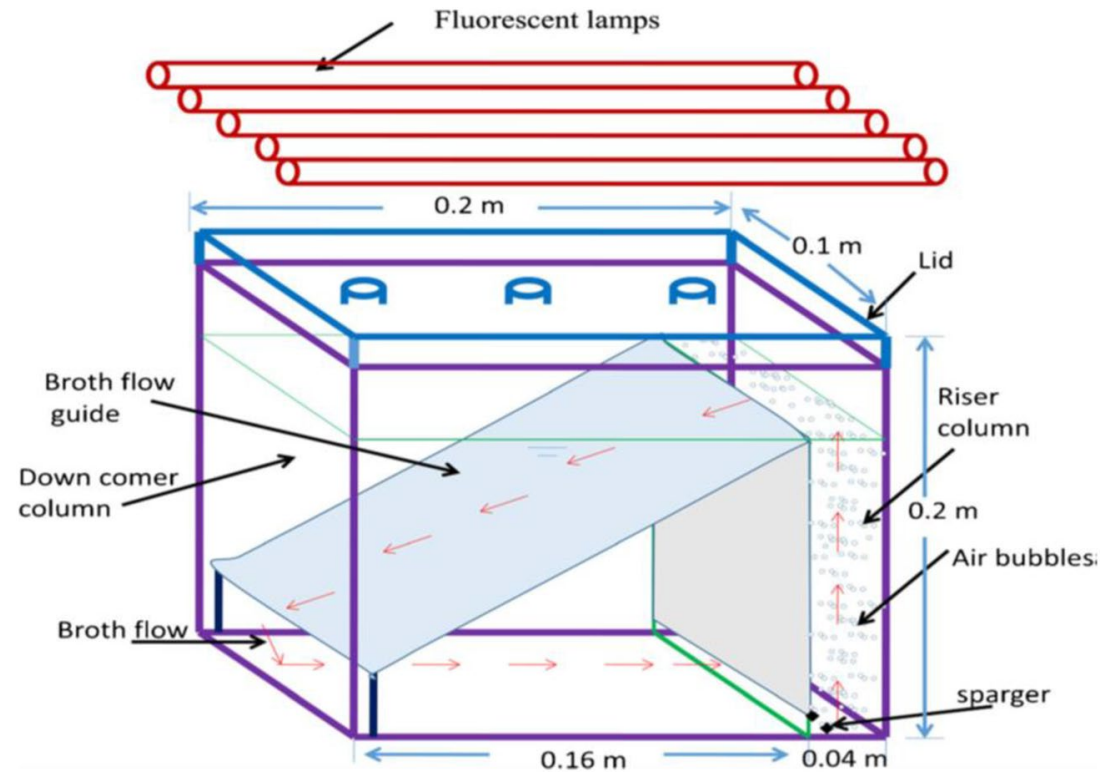


were monitored by measuring the OD and converting to dry cell weights from a OD vs dry cell weight calibration curve. The specific growth rates $\mu\left(\right.$ day $\left.^{-1}\right)$ were calculated as $1 / \mathrm{t} \times \ln \left(\mathrm{X}_{\mathrm{m}} / \mathrm{X}_{0}\right)$. Here, $\mathrm{X}_{0}\left(\mathrm{~g} \mathrm{~L}^{-1}\right)$ is the cell concentration on day $3 ; \mathrm{X}_{\mathrm{m}}\left(\mathrm{g} \mathrm{L}^{-1}\right)$ is the cell concentration on day 7 while $\mathrm{t}$ (day) is 4 days.

\section{Carotenoid and protein contents of the cells}

Broth sample $(5.0 \mathrm{~mL})$ was centrifuged at $5000 \times \mathrm{g}$ for $5 \mathrm{~min}$ and washed two times with distilled water. The carotenoid was extracted from the cell pellet by suspending the cell in $5.0 \mathrm{~mL} 90 \%(\mathrm{v} / \mathrm{v})$ methanol for $24 \mathrm{~h}$ and centrifuging at $5000 \times g$ for $5 \mathrm{~min}$ (Becker 1994). The absorbance of the extract (the supernatant) was measured at $470 \mathrm{~nm}$ and $660 \mathrm{~nm}$ using UV-VIS spectrometer. Total carotenoid $\left(\mathrm{mg} \mathrm{L}^{-1}\right)$ was calculated as $\left(1000 \mathrm{~A}_{470}-44.76 \mathrm{~A}_{666} / 221\right)$ as reported by Lichtenthaler (1987).

Protein was extracted from the dry biomass sample by dissolving $0.1 \mathrm{~g}$ pulverized sample in $3.0 \mathrm{~mL} 1 \mathrm{M} \mathrm{NaOH}$, and boiling for $20 \mathrm{~min}$ according to Rausch, (1981). The protein extract was recovered by centrifuging at $5000 \times \mathrm{g}$ for 5 min and quantified with Coomassie Brilliant Blue (Bradford, 1976).

\section{Statistical analysis}

The data were subjected to Analysis of Variance (ANOVA) single classification. The number of replicates was four and the data were presented or plotted as mean \pm S.E. Least significance difference (LSD) was used to evaluate differences between mean values.

\section{Results and discussion}

\section{Identification of the isolates}

These microalgae strains were previously identified and ascribed to the genera: Oocystis A1, Chlorella A7, Chlorococcum $A 9$ and Botyrococcus A5 based on their morphological characteristics under light microscope (Table 1)
(Ogbonna and Ogbonna 2015). This method of identification is not accurate because the media, the general culture conditions and the stage of growth can have significant effects on the cell morphology even though it is still frequently used to identify microalgae (Cobos et al. 2017). For instance, the same strain of microalgae at different age and culture condition exhibit morphological variations (Yu et al. 2012). Consequently, the use of genetic sequences to identify species as in the present study is more appropriate (Kaur et al. 2012), since the ITS2 rDNA can differentiate closely-related organisms with almost identical sequences (Coleman 2009).

The accession numbers of ITS rDNA (730 bp) sequences of the microalgae strains published in the NCBI database and their previous names is presented in Table 1. Phylogenetic analysis of the ITS region (730 bp) showed that there are three clusters and each contain different genera of microalgae (Fig. 2). The first cluster, for example, consisted of Desmodesmus and two other strains (A1 and A7). The second cluster consisted of Dictyosphaerium genera and one microalga strain A5 while the third cluster consisted of the Chlorella genera and microalga strain A9. The strains; A1, A5, A7, and A9 had 99\% identity with D. armatus, Dictyosphaerium sp, D. subspicatus and C. lewinii respectively (Fig. 2). Among these genera of microalgae, Chlorella sp are already well-studied, having wide report in literature, and are currently cultivated for commercial use (Koyande et al. 2019). However, other genera especially Desmodesmus sp. have few reports in literature (Pozzobon et al. 2020) probably because few studies have been done on them.

\section{Cultivation of microalgae species in flask cultures}

BG 11 medium is a basic medium used to cultivate various species of microalgae (Covell et al. 2020) which informed the authors' choice in the current study. The growth rates and the final biomass concentrations of the four species of the microalgae varied significantly in BG 11 medium (Fig. 3b). Although the growth rate for D. subspicatus was the highest $\left(0.20 \pm 0.006 \mathrm{day}^{-1}\right)$, there was no significant difference between the final biomass concentration (0.9 $\mathrm{gL}^{-1}$ ) and that of $C$. lewinii after 8 days of cultivation. This result is consistent with previous reports that culture

Table 1 GenBank accession numbers of ITS2 sequences, biomass productivity and carotenoid productions by some freshwater microalgae strains in batch flask cultures

\begin{tabular}{llllll}
\hline Source names & Strain & Genera/Species & $\begin{array}{l}\text { GeneBank accession } \\
\text { numbers }\end{array}$ & $\begin{array}{l}\text { Biomass productivity g } \\
\mathrm{L}^{-1} \text { day }^{-1}\end{array}$ & $\begin{array}{l}\text { Carotenoid } \\
\text { productions mg } \\
\mathrm{L}^{-1}\end{array}$ \\
\hline Oocystis sp. & A1 & Desmodesmusarmatus & LC172263 & $0.091 \pm 0.001$ & $1.095 \pm 0.003$ \\
Chlorella sp. & A7 & Desmodesmussubspicatus & LC172266 & $0.109 \pm 0.001$ & $2.001 \pm 0.004$ \\
Chlorococcum sp. & A9 & Chlorella lewinii & LC172265 & $0.11 \pm 0.002$ & $1.848 \pm 0.003$ \\
Botyrococcus sp. & A5 & Dictyosphaeriumsp & LC172264 & $0.075 \pm 0.003$ & $1.62 \pm 0.004$ \\
\hline
\end{tabular}


Fig. 2 Phylogenetic tree of microalgae strains using the ITS2 sequences. The tree was constructed by the neighborjoining algorithm and the Bootstrap values of 1000 replicates (\%) are shown at the branches

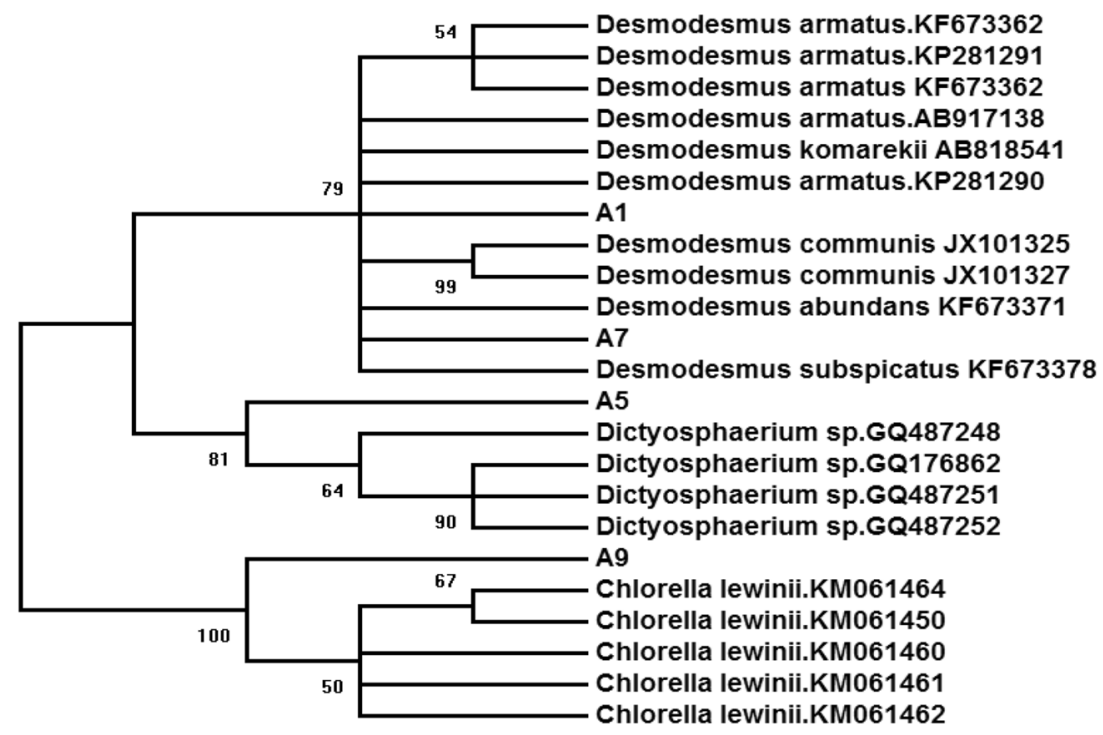

media affect the growth and biomass productivities of microalgae species (Covell et al. 2020; Loganathan et al. 2020). There were also variations in the $\mathrm{pH}$ of the culture broth during cultivation. The $\mathrm{pH}$ increased from an initial value of 7-9.5 for C.lewinii and D. armatus but for $C$. lewinii and Dictyosphaerium, sp, the $\mathrm{pH}$ increased to 10 and 11.25 , respectively (Fig. 3d). According to Loganathan et al. (2020), the $\mathrm{pH}$ trend of 7-9 during cultivation favored good nutrient assimilation and was appropriate for the growth of microalgae species, while higher $\mathrm{pH}$ trend limits the absorption of trace metals which are essential in photosynthesis. This view is consistent with the present result in that the species whose culture medium maintained a pH of 7-9 had the best growth while Dictyosphaerium sp whose $\mathrm{pH}$ exceeded 11 recorded the least growth rate and final biomass concentration (Fig. 3b, d). Loganathan et al. (2020) also reported that $\mathrm{pH}$ of 10.15 in MZM medium impacted negatively on the cell growth and productivity of Chlorella variabilis. Furthermore, the preference to nitrogen sources by some microalgae species is probably on the basis of easier assimilation (Minyuk et al. 2020), and the nitrogen to phosphorus ratio of the culture medium (Loganathan et al. 2020) have been implicated for either high or low growth and productivities. For instance, MN8 medium with a ratio of nitrogen to phosphorus of 1:3 supported higher growth rate and biomass concentration in $C$. vulgaris culture. These effects might be specie-specific as Pandey et al. (2020) reported that BG 11 medium elicited the highest growth rate $\left(0.32 \mathrm{day}^{-1}\right)$ by Scenedesmus sp ASK22 under heterotrophic condition among five selected media, some of which the N: P ratios were higher. Comparing Pandey et al.'s report, the present report on flask culture had higher growth rates $\left(0.50 \mathrm{day}^{-1}\right)$ probably due to difference in the species as well as other culture conditions.

Carotenoid accumulation by Dictyosphaerium sp was the highest but there was no significant difference between the carotenoid contents of $C$. lewinii and D. subspicatus while $D$ armatus had the least carotenoid content. On the other hand, there were no significant differences among the protein contents of Dictyosphaerium $\mathrm{sp}$, D. subspicatus and $D$. armatus while $C$. lewinii had the least protein content (Fig. 3b, c). On the whole, D. subspicatus gave the highest carotenoid productivity $\left(0.25013 \pm 0.01 \mathrm{mgL}^{-1} \mathrm{day}^{-1}\right)$ after 8 days of cultivation. The preference to nitrogen sources is known to affect the rate of absorption by different algal species (Minyuk et al. 2020), and this affects intracellular concentrations of metabolites. The increase in protein and carotenoid contents as the biomass concentration increased suggests that protein and carotenoid accumulation in these microalgae species were growth-dependent. Loganathan et al. (2020) also reported that protein content and primary carotenoid (lutein) increased with cell growth in C. variabilis under nitrogen sufficient condition. Primary carotenoids accumulate under nutrient sufficient condition as obtained in the present study which may suggest that the carotenoids accumulated by $D$. subspicatus were primary carotenoids. Although protein is generally accumulated in microalgae at increased nitrogen concentration, carotenoid accumulation could be dependent on nitrogen source concentration or type of species (Zhuang et al. 2018).

According to literature, growth rate and biomass productivity are very strong indices that point to the commercial potential of microalgae technology (Loganathan et al. 2020). Consequently, D. subspicatus was selected for further studies. The impact of urea supplementation 

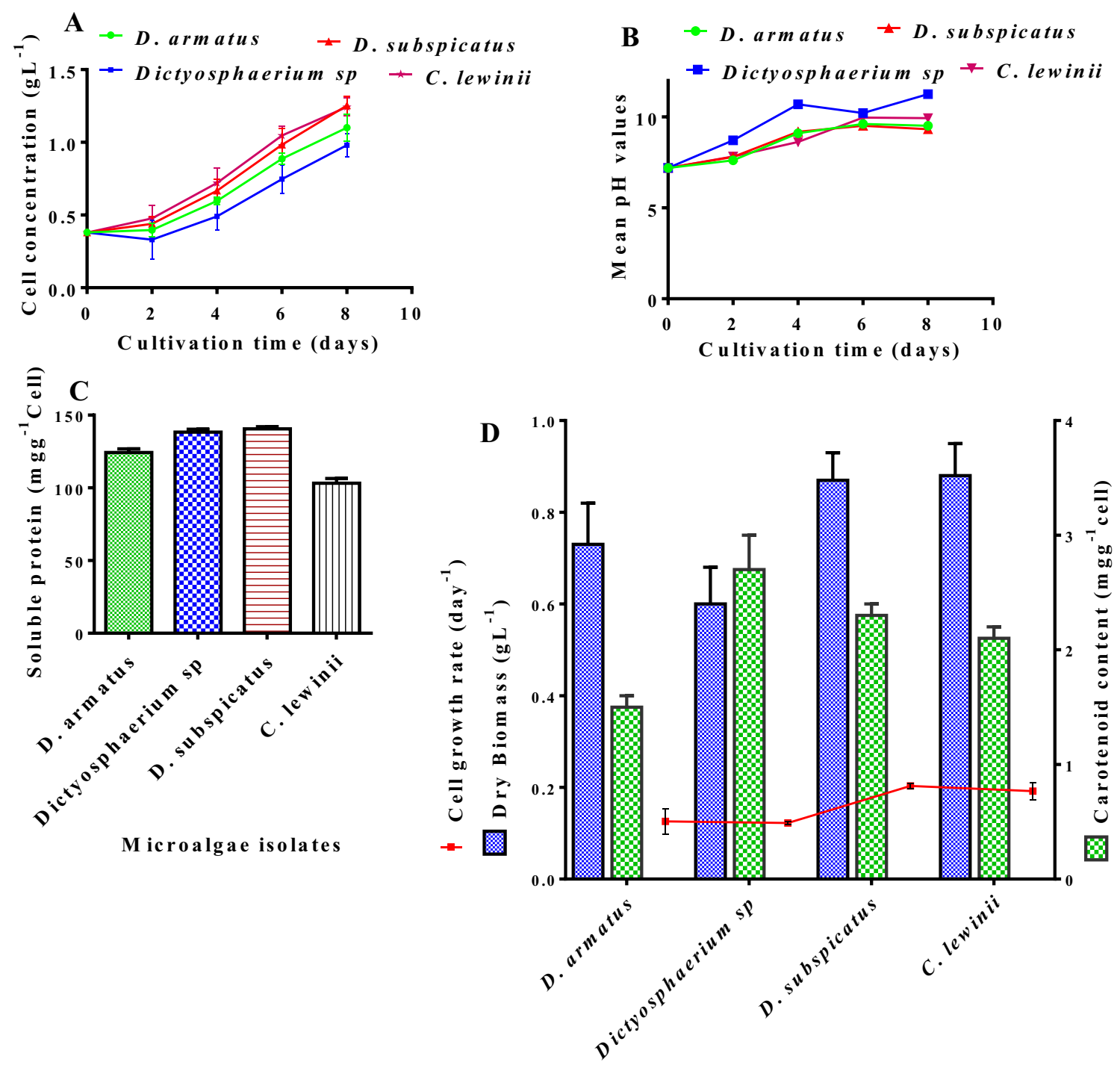

Microalgae isolates

Fig. 3 The growth curves (a), pH changes (b), protein content (c), biomass and carotenoid contents (d), during flask cultivation of four freshwater microalgae species

to BG11 medium on growth rate and biomass concentration of D. subspicatus was investigated under mixotrophic condition as shown in Fig. 4. The results showed that supplementation of urea to sodium nitrate in BG 11 medium resulted in higher cell growth and biomass concentrations compared to the control 1 (without urea supplementation) and control 2 (urea without sodium nitrate). This may be due to the impact of urea on nitrate assimilation by $D$. subspicatus (Eze et al. 2020). More importantly, urea-N is acknowledged as a cheap nitrogen source for microalgae production which has cost-effective advantage during commercial production (Zhuang et al. 2018). Hence, the choice of urea as nitrogen supplement to BG 11 medium in the present study.

\section{Cultivation in the flat plate airlift photobioreactor with broth circulation guides.}

The results from the flask cultures have demonstrated that D. subspicatus has the potentials for carotenoid production. However, the full potentials can only be realized if cultivated in a good photobioreactor with good mixing and light distribution. The effectiveness of the novel photobioreactor equipped with broth circulation guides (Eze et al. 2017) in enhancing carotenoid production by D. subspicatus was therefore investigated, using BG 11 medium supplemented with $0.2 \mathrm{gL}^{-1}$ urea-N at $100 \mu \mathrm{mol}$ photons $\mathrm{m}^{-2} \mathrm{~s}^{-1}$ light intensity. Installation of transparent or opaque broth circulation guides resulted in better cell 


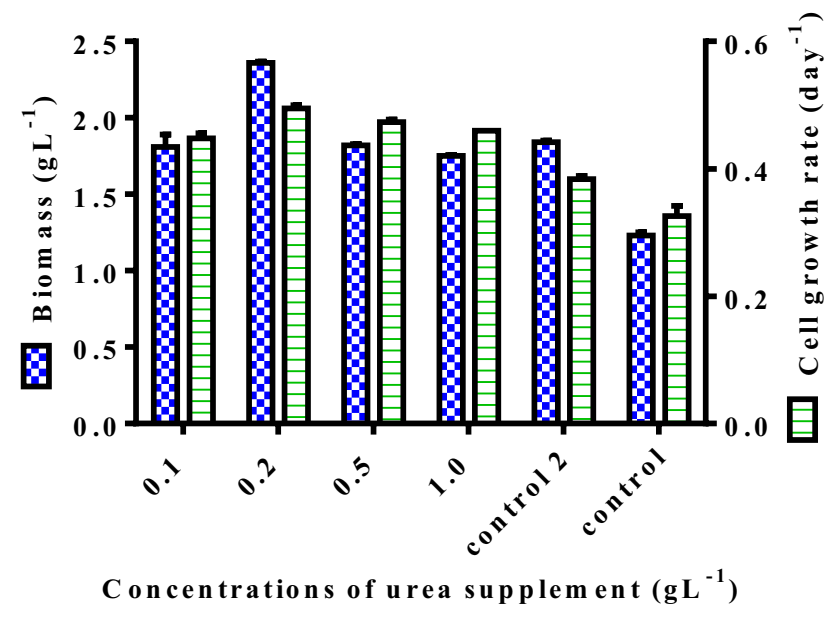

Fig. 4 Effect of different concentrations of urea supplement on growth of D. subspicatus LC172266 in BG11 supplemented with $5.0 \mathrm{gL}^{-1}$ glucose. Control (without urea supplementation). Control 2 (urea without nitrate)

growth but had no significant improvement in the carotenoid content. However, with reflective broth circulation guide, both the biomass concentration and cellular carotenoid contents were significantly higher than the values obtained without any guide (control), opaque or transparent broth circulation guides. The carotenoid productivity, biomass concentration and protein contents obtained with the novel photobioreactor equipped with reflective broth circulation guide were about 14 times, 1.5 times and 2.5 times respectively higher than the values produced in flask culture (Figs. 5b, 6, 7). All the three broth circulation guides (opaque, transparent and reflective) improved mass transfer as measured by broth circulation time and mixing time (Eze et al. 2017). The higher cell growth rates obtained in the photobioreactor with transparent and opaque broth circulation guides can be partly attributed to better mass transfer. However, it is apparent that this did not affect the carotenoid content of the cells. The very significant effect of reflective broth circulation guide is therefore mainly due to improved distribution of light inside the photobioreactor (Ogbonna and Tanaka 2000; Khan et al. 2018).

The $\mathrm{pH}$ profile of culture medium during cell cultivation with each of the broth circulation guides were all within the range of 7-9 (Fig. 5a) which reflected nutrient assimilation as discussed in Sect. 3.2. However, reflective and opaque broth circulation guides showed more favorable $\mathrm{pH}$ range of 7-8 with higher cell growth and productivities (Figs. 5a, b, 6, and 7). The cell growth rate and carotenoid productivity by the microalga in the photobioreactor equipped with reflective broth circulation guide was about twice higher than the value produced in photobioreactor installed with either transparent, opaque broth circulation guides or control (without broth guide) (Figs. 5b and 6).

The effectiveness of the present photobioreactor in enhancing bio-lipid accumulation by $D$. subspicatus, on the basis of enhanced mixing and light irradiance in the internal regions of the culture has been reported previously (Eze et al. 2017). In another study on phototrophic cultivation of Chlorococcum humicola, the difference in photobioreactor design was highlighted for the higher biomass and carotenoid productivity observed in air-lift photobioreactor than in stirred-tank photobioreactor (Powtongsook and Nootong 2019). The biomass concentration obtained in the present study $\left(1.4 \mathrm{gL}^{-1}\right)$ is much higher than the value reported for Chlorococcum humicola when cultivated in air-lift photobioreactor $\left(0.9 \mathrm{gL}^{-1}\right)$ for 14 days. This is probably due to differences in the culture operational conditions (aeration content, aeration rate and light intensity) and species of microalgae involved.
Fig. 5 The $\mathrm{pH}$ changes during cultivation (a), biomass and carotenoid contents (b), of Desmodesmus subspicatus LC172266 during cultivation in a 4-L flat plate airlift photobioreactor with broth circulation guides. Control $=$ no broth circulation guide
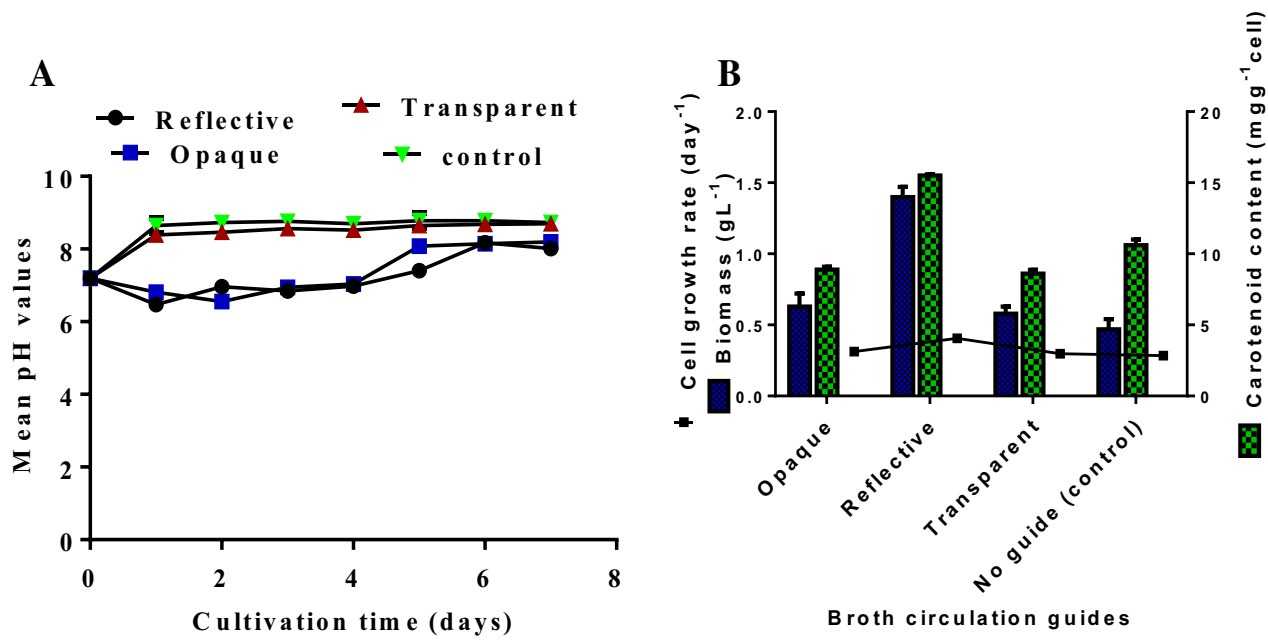


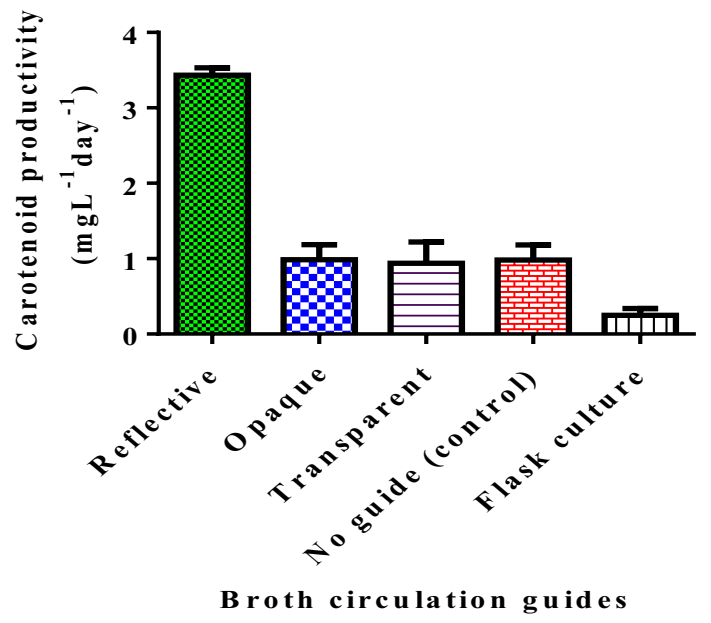

Fig. 6 Carotenoid accumulation in D. subspicatus $\mathbf{L C 1 7 2 2 6 6}$ during cultivation in a 4-L flat plate airlift photobioreactor with broth circulation guides

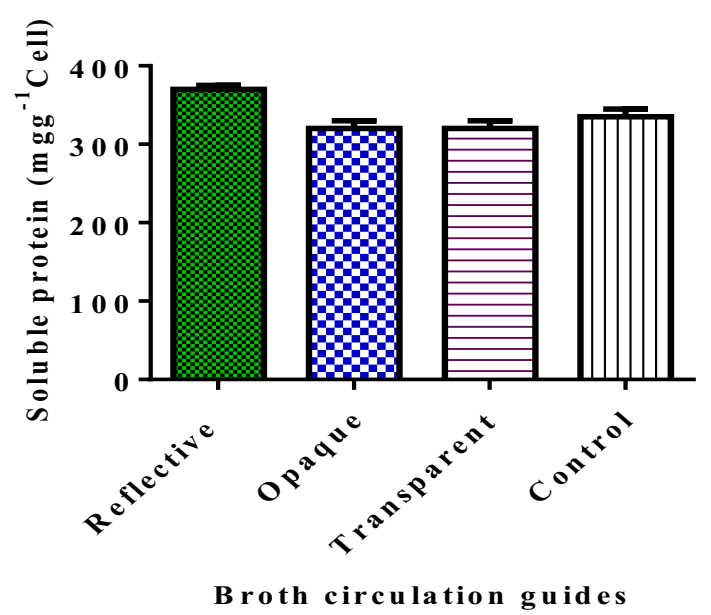

Fig. 7 Effect of the type of broth circulation guides on the protein content of Desmodesmus subspicatus LC172266 in the novel photobioreactor. Control $=$ no broth circulation guide

\section{The Impact of nitrogen source concentrations and light intensity}

The nature and concentrations of nitrogen sources, as well as light intensities are important factors affecting pigment and protein accumulation (Benavente-Valdes et al. 2016; Eze et al. 2020; Schüler et al. 2020), growth and biomass productivities (Huo et al. 2018; Zhu et al. 2019) by many species of microalgae. The impact of urea supplementation on cell growth in flask cultures has been shown (Fig. 4). The supplementation of BG 11 with the optimum urea concentration $\left(0.2 \mathrm{gL}^{-1}\right)$ elicited increased growth rate and biomass concentration by about $51 \%$ and $92 \%$ respectively when compared to the control (without urea supplementation). However, further increases in biomass concentration $\left(1.4 \mathrm{gL}^{-1}\right)$ and carotenoid contents $\left(15.5 \mathrm{mgg}^{-1}\right)$ were obtained by cultivation in the photobioreactor with reflective broth circulation guide. These values were significantly higher $(\mathrm{p}<0.05)$ than the values obtained in the photobioreactors equipped with either transparent $\left(0.58 \mathrm{gL}^{-1}\right.$ and $\left.8.6 \mathrm{mgg}^{-1}\right)$ or opaque broth circulation guides $\left(0.63 \mathrm{gL}^{-1}\right.$ and $\left.8.9 \mathrm{mgg}^{-1}\right)$ (Fig. $5 \mathrm{~b}$ ). The enhanced productivity is attributed most probably to better light distribution by the reflective broth guide whose reflection improved light distribution inside the photobioreactor (Eze et al. 2017). The opaque broth circulation guide gave slightly higher productivity than transparent guide probably due to flashing light effect that characterized the photobioreactor with opaque broth circulation guide. This is known to enhance light utilization, though at very high light intensities (Schulze et al. 2017). Madhubalaji et al. (2019) observed the highest biomass $\left(1.13 \mathrm{gL}^{-1}\right)$, growth rate $\left(0.45 \mathrm{day}^{-1}\right)$, carotenoids $\left(7.97 \mathrm{mgg}^{-1}\right)$ and protein $(69.68 \% \mathrm{w} / \mathrm{w})$ at increased light intensity up to $400 \mu \mathrm{mol} \mathrm{m} \mathrm{m}^{-2} \mathrm{~s}^{-1}$ by $C$. vulgaris cultivated in airlift photobioreactor. The medium was nitrogen-sufficient modified Bold Basal medium. In another report, there was increased biomass production of Eustigmatos $c f$. polyphem at increased light intensity from low light intensity $\left(100 \mu \mathrm{mol}\right.$ photons $\left.\mathrm{m}^{-2} \mathrm{~s}^{-1}\right)$ to high light intensity $\left(300 \mu \mathrm{mol}\right.$ photons $\left.\mathrm{m}^{-2} \mathrm{~s}^{-1}\right)$ with all the nitrogen sources tested (Gao et al. 2017). However, Pozzobon et al. (2020) recently reported that during cultivation of Desmodesmus sp. in a bubble column photobioreactor with nitrogen-rich BN3 medium, increasing the light intensity from 75 to $150 \mu \mathrm{mol}$ photons $\mathrm{m}^{-2} \mathrm{~s}^{-1}$ gave the same growth rate $\left(0.0469 \mathrm{~h}^{-1}\right)$ while increasing from 150 to $300 \mu \mathrm{mol}$ photons $\mathrm{m}^{-2} \mathrm{~s}^{-1}$ gave the same lutein content (0.251-0.244 $\left.\pm 0.005 \% \mathrm{gg}^{-1} \mathrm{DW}\right)$. Furthermore, Gonclaves et al. (2019) reported that nitrogen concentration did not have significant effect on Tetradesmus acuminatus (LC192133.1) cultivated in photobioreactor at different light intensities. In some earlier studies on Scenedesmus spp., nitrogen sufficiency and high light intensity induced the greatest carotenoid accumulation (about $7.0 \mathrm{mgg}^{-1}$ ) in an outdoor thin-layer photobioreactor (Pribyl et al. 2016) and fed batch air-lift photobioreactor $\left(11.99 \mathrm{mgg}^{-1}\right)(\mathrm{Gar}-$ cia-Canedo et al. 2016). Although the carotenoid contents were lower than the current report, they were all in agreement in terms of increased productivities under nitrogenrich and increased light supply conditions. In another study, the carotenoids and protein contents of Chlorella vulgaris ( $a$ chlorophyll-deficient mutant) were reportedly enhanced by light irradiance under mixotrophic condition using F2 Guillard medium (Schüler et al. 2020). Although the authors attributed the higher protein content in the mutant to induction of larger photosynthetic units such as 
chlorophyll-binding proteins and thylakoid proteins in the presence of light, the nitrate nutrient-sufficient F2 Guillard medium may have contributed to the same effect.

It is noteworthy that this trend in carotenoid accumulation differs from the widely reported stress-induced accumulation by many microalgae species (Koyande et al. 2019; Novoveska et al. 2019; Panahi et al. 2019). A possible explanation to this trend of carotenoid accumulation might be that different regulatory mechanisms of carotenoid biosynthesis function in these species (Pribyl et al. 2016). This trend in carotenoid accumulation is very important because the feature suggests a potential for production of carotenoid-rich biomass which offers cost effective advantage at commercial production. In fact, by way of comparison, the carotenoid production in the present report is higher than some recent reports by other species (Table 2). The importance of this outcome is that Desmodesmus spp. which hitherto has few reports compared to Chlorella spp in literature (Pozzobon et al. 2020), should attract more attention for more research to establish its potential commercial value. For instance, the simultaneous increase in protein and carotenoids concentrations by $D$. subspicatus in the present work indicates a potential as food/feed supplement.

The recent reports on the potential of Dunaliella salina for human food due to co-production of quality protein and carotenoid in a two-phase culture system for 20 days (Sui et al. 2019), and production of Chlorella vulgaris biomass with enhanced pigment $(52.18 \pm 1.30 \%$ of DW) and protein $\left(23.98 \pm 1.57 \mathrm{mg} \mathrm{g}^{-1} \mathrm{DW}\right)$ contents in a two-phase heterotrophic-phototrophic culture system for 14 days (Barros et al. 2019) highlights more the potentials of the present report. For instance, the single-phase culture system of the present report which supported increased simultaneous production of protein and carotenoids holds more cost effective advantage than the two-phase system reported. The higher protein and carotenoid concentrations reported by Sui et al. (2019) may be specie-specific or due to length of cultivation. However, the protein content reported by Barros et al. (2019) was significantly lower than the current report probably due to differences in species and culture conditions.

\section{Conclusions}

The data obtained in this work have demonstrated the potentials of D. subspicatus $\mathbf{L C 1 7 2 2 6 6}$ as a source of carotenoids, and that its growth and carotenoid productivities can be improved by urea supplementation as well as improvement in mass transfer and light distribution inside the bioreactors. These were achieved by cultivation in the novel flat plate airlift photobioreactor with reflective broth circulation guide. Simultaneous accumulation of protein and carotenoid by $D$. subspicatus indicates that it has a potential as a food/ feed supplement.

Table 2 Comparison of carotenoids production by some species of microalgae

\begin{tabular}{|c|c|c|c|c|}
\hline Microalgae species & $\begin{array}{l}\text { Carotenoid } \\
\text { content (mg } \\
\left.\mathrm{g}^{-1}\right)\end{array}$ & $\begin{array}{l}\text { Carotenoid } \\
\text { productivity (mg } \\
\left.\mathrm{L}^{-1} \mathrm{day}^{-1}\right)\end{array}$ & Culture conditions & References \\
\hline DesmodesmussubspicatusLC172266 & 15.5 & 3.43214 & $\begin{array}{l}\text { BG II medium, } 0.2 \mathrm{gL}^{-1} \text { Urea-N } \\
\text { supplement, } 30^{0} \mathrm{C} \text {; light: } 100 \mu \mathrm{mol} \text {. } \\
\mathrm{m}^{-2} \mathrm{~s}^{-1}, 7 \text { day }\end{array}$ & Present study \\
\hline C. zofingiensis & 21.805 & 1.36281 & $\begin{array}{l}\text { Bold Basal medium, Bipha- } \\
\text { sic: photo-mixotrophy:, } 120- \\
240 \mu \mathrm{mol} \mathrm{m}-{ }^{2} \mathrm{~s}-{ }^{1}, 20-25^{\circ} \mathrm{C}, 32 \\
\text { day }\end{array}$ & Minyuk et al. (2020) \\
\hline $\begin{array}{l}\text { Asterarcysquadricellu- } \\
\text { larePUMCC5.1.1 }\end{array}$ & 118 & 8.85 & $\begin{array}{l}\text { Bold Basal medium, } 10 \mathrm{mM} \text {, } \\
\text { nitrate, } 3.5 \mathrm{mM} \text { phosphate, } 0.17 \mathrm{mM} \\
\text { salinity, light intensity: } 60 \\
\mu \text { molm }{ }^{-2} \mathrm{~s}^{-1} \text { photon flux. } 36 \text { day }\end{array}$ & Singh et al. (2019) \\
\hline Desmodesmus. subspicatusMB.23 & 4.6 & 0.27804 & $\begin{array}{l}\text { BBM, NPK fertilizer supplemented, } \\
\text { light: } 39 \mu \mathrm{mol} \mathrm{m}^{-2} \mathrm{~s}^{-1} \text {, L-D cycle, } \\
45 \text { day }\end{array}$ & Abdulsamad et al. (2019) \\
\hline Chlorella sorokinianaMB-1-M12 & 4.98 & 6.61 & $\begin{array}{l}\text { BG-11medium, } 6 \mathrm{gL}^{-1} \text { sodium } \\
\text { acetate, } 75 \% \text { medium replacement, } \\
\text { light: } 150 \mu \mathrm{molm}^{-2} \cdot \mathrm{s}^{-1}, 28{ }^{\circ} \mathrm{C} 15-21 \\
\text { day }\end{array}$ & Chen et al. (2019) \\
\hline Dunaliellaparva (D-PSY) & 7.0 & $\mathrm{~Np}$ & $\begin{array}{l}\text { Johnsosns medium, } 25 \pm 1^{\circ} \mathrm{C} \text { light: } \\
50 \mu \mathrm{mol} \mathrm{m}-{ }^{2} \mathrm{~s}-{ }^{1}, 30 \mathrm{ppm} \text { polyeth- } \\
\text { ylene glycol stress, } 16 \text { day }\end{array}$ & Ismaiel et al. (2018) \\
\hline
\end{tabular}

$n p$ not provided 
Acknowledgements This study was supported by Japan Students Services Organization-JASSO (Students Exchange Department) in Prof. Hideki Aoyagi's Laboratory, Faculty of Life and Environmental Sciences, University of Tsukuba.

Author contributions JCO: Conceptualized, designed the experiments, supervised the work, reviewed and edited the manuscript. HA: Supervised the work and provided bench space for the experiments. CNE: Conducted the experiments and prepared the original draft of the manuscript. IOO: Isolated the microalgae, reviewed and edited the manuscript.

Funding This research did not receive any specific grant from funding agencies in the public, commercial, or not-for-profit sectors.

\section{Declarations}

Competing interest There is no conflict of interest. The microalgae were isolated by the authors and maintained in our laboratory for research purposes.

Statement of informed consent, human/animal rights No conflicts, informed consent, human or animal rights is applicable.

\section{References}

Abdulsamad JK, Varghese SA, Thadjudin A (2019) Cost effective cultivation and biomass production of green microalga Desmodes mus subspicatus MB. 23 in NPK fertilizer medium. J Microbiol Biotechnol Food Sci 9:599-604. https://doi.org/10.15414/jmbfs. 2019/20.9.3.599-604

Barros A, Pereira H, Campos J, Marques A, Varela J, Silva J (2019) Heterotrophy as a tool to overcome the long and costly autotrophic scale-up process for large scale production of microalgae. Sci Rep 9:13935. https://doi.org/10.1038/s41598-019-50206-z

Becker EW (1994) Microalgae: Biotechnology and Microbiology. Cambridge University Press, Cambridge UK, p 293 (978-0-521-06113)

Benavente-Valdes JR, Aguilar C, Contrares-Esquivel JC, MemndezZavala A, Montanez J (2016) Strategies to enhance the production of photosynthetic pigments and lipids in chlorophycae species. Biotechnol Reports 10:117-125. https://doi.org/10.1016/j.btre. 2016.04.001

Bradford MM (1976) A rapid and sensitive method for the quantitation of microgram quantities of protein utilizing the principle of protein-dye binding. Anal Biochem 72:248-254. https://doi.org/ 10.1016/0003-2697(76)90527-3

Cardoso LAC, Kanno KYF, Karp SG (2017) Microbial production of carotenoids-a review. Afr J Biotechnol 16:139-146. https://doi. org/10.5897/AJB2016.15763

Cezare-Gomes EA, Mejia-da-Silva LDC, Perez-Mora LS, Matsudo MC, Ferreira-Camargo LS, Singh AK, Carvalho JCMD (2019) Potential of microalgae carotenoids for industrial application. Appl Biochem Biotechnol 188:602-634. https://doi.org/10.1007/ s12010-018-02945-4

Chen J-H, Chen C-Y, Hasunuma T, Kondo A, Chang H-C, Ng I-S, Chang J-S (2019) Enhancing lutein production with mixotrophic cultivation of Chlorella sorokiniana MB-1-M12 using different bioprocess operation strategies. Bioresour Technol 278:17-25. https://doi.org/10.1016/j.biortech.2019.01.041

Cobos M, Paredes JD, Maddox JD, Vargas-Arana G, Flores L, Aguilar CP, Marapara JL, Castro JC (2017) Isolation and characterization of native microalgae from the Peruvian amazon with potential for biodiesel production. Energies 10:224. https://doi.org/10.3390/ en10020224

Coleman AW (2009) Is there a molecular key to the level of "biological species" in eukaryotes? A DNA Guide. Mol Phylogenet Evol 50:197-203. https://doi.org/10.1016/j.ympev.2008.10.008

Covell L, Machado M, Vaz MGMV, Soares J, Batista AD, Arajuo WL, Martins MA, Nunes-Nesi A (2020) Alternative fertilizer based growth media support high lipid contents without growth impairment in Scenedesmus obliquus BR003. Bioproc Biosyst Eng 43:1123-1131. https://doi.org/10.1007/s00449-020-02301-z

Dolganyuk V, Belova D, Babich O, Prosekov A, Ivanova S, Katserov D, Patyukov N, Sukhikh S (2020) Microalgae: a promising source of valuable bioproducts. Biomolecules 10:1153. https://doi.org/ 10.3390/biom 10081153

Eida MF, Darwesh OM, Matter IA (2018) Cultivation of oleaginous microalgae Scenedesmus obliquus on secondary treated municipal wastewater as growth medium for biodiesel production. J Ecol Eng. 19:38-51. https://doi.org/10.12911/22998993/91274

Ejike CECC, Collins SA, Balasuriya N, Swanson AK, Mason B, Udenigwe CC (2017) Prospects of microalgae proteins in producing peptide-based functional foods for promoting cardiovascular health. Trends Food Sci Technol 59:30-36

Eze CN, Ogbonna JC, Ogbonna IO, Aoyagi H (2017) A novel flat plate air-lift photobioreactor with inclined reflective broth circulation guide for improved biomass and lipid productivity by Desmodesmus subspicatus LC172266. J Appl Phycol 29:2745-2754. https:// doi.org/10.1007/s10811-017-1153-z

Eze CN, Aoyagi H, Ogbonna JC (2020) Simultaneous accumulation of carotenoids and lipid in freshwater green microalga Desmodesmus subspicatus LC172266 by nutrient replete strategy under mixotrophic condition. Korean J Chem Eng 37(2):1-8. https://doi.org/ 10.1007/s11814-020-0564-8

Felsenstein J (1985) Confidence limits on phylogenies: an approach using the bootstrap. Evol 39:783-791. https://doi.org/10.1111/j. 1558-5646.1985.tb00420.x

Gao B, Xia S, Lei X, Zhang C (2017) Combined effects of different nitrogen sources and levels and light intensities on growth and fatty acid and lipid production of oleaginous Eustigmatophycean microalga Eustigmatos cf. polyphem. J Appl Phycol 30:215-229. https://doi.org/10.1007/s10811-017-1180-9

Garcia-Canedo JC, Cristiani-Uribina E, Flores-Ortiz CM, Ponce-Noyola T, Esparza-Garcia F, Canizares-Villanueva RO (2016) Batch and fed-batch culture of Scenedesmus incrassatulus: effect over biomass, carotenoid profile and concentration, photosynthetic efficiency and non-photochemical quenching. Algal Res 13:41-52. https://doi.org/10.1016/j.algal.2015.11.013

Gonclaves VD, Fagundes-Klen MR, Trigueros DEG, Kroumove AD, Modenes AN (2019) Statistical and optimization strategies to carotenoids production by Tetradesmus acuminatus (LC192133.1) cultivated in photobioreactors. Biochem Eng J 152:1-10. https:// doi.org/10.1016/j.bej.2019.107351

Huang Q, Jiang F, Wang L, Yang C (2017) Design of photobioreactors for mass cultivation of photosynthetic organisms. Engin 3:318 329. https://doi.org/10.1016/J.ENG.2017.03.020

Huo S, Wang Z, Zhu S, Shu Q, Zhu L, Qin L, Zhou W, Feng P, Zhu F, Yuan Z, Dong R (2018) Biomass accumulation of Chlorella zofingiensis $\mathrm{G} 1$ cultures grown outdoors in photobioreactors. Front Energy Res 6:49-57. https://doi.org/10.3389/fenrg.2018.00049

Ismaiel MMS, El-Ayouty YM, Said AA, Fathey HA (2018) Transformation of Dunaliella parva with PSY gene: Carotenoids show enhanced antioxidant activity under polyethylene glycol and calcium treatments. Biocat Agric Biotechnol 16:378-384. https://doi. org/10.1016/j.bcab.2018.09.011

Kaur S, Sarkar M, Srivastava RB, Gogoi HK, Kalita MC (2012) Fatty acid profiling and molecular characterization of some freshwater microalgae from India with potential for biodiesel production. 
New Biotechnol 29:332-344. https://doi.org/10.1016/j.nbt.2011. 10.009

Khan MI, Shin JH, Kim JD (2018) The promising future of microalgae: current status, challenges, and optimization and renewable industry for biofuels, feed, and other products. Microb Cell Fact 17:36. https://doi.org/10.1186/s12934-018-0879-x

Koyande AK, Chew KW, Rambabo K, Tao Y, Chu D-T, Show P-L (2019) Microalgae: A potential alternative to health supplementation for humans. Food Sci Hum Wellness 8:16-24. https://doi.org/ 10.1016/j.fshw.2019.03.001

Lichtenthaler HK (1987) Chlorophylls and carotenoids, pigments of photosynthetic biomembranes. Methods Enzymol 148:350-382. https://doi.org/10.1016/0076-6879(87)48036-1

Loganathan BG, Orsat V, Lefsrud M (2020) Evaluation and interpretation of growth, biomass productivity and lutein content of Chlorella variabilison various media. J Environ Chem Eng 8:103750. https://doi.org/10.1016/j.jece.2020.103750

Madhubalaji CK, Chandra TS, Chauhan VS, Sarada R, Mudliar SN (2019) Chlorella vulgaris cultivation in airlift photobioreactor with transparent draft tube: effect of hydrodynamics, light and carbon dioxide on biochemical profile particularly $\mathrm{x}-6 / \mathrm{x}-3$ fatty acid ratio. J Food Sci Technol 57:866-876. https://doi.org/10. 1007/s13197-019-04118-5

Minyuk G, Sidorov R, Solovchenko A (2020) Effect of nitrogen source on the growth, lipid, and valuable carotenoid production in the green microalga Chromochlorisz of ingiensis. J Appl Phycol 32:935. https://doi.org/10.1007/s10811-020-02060-0

Mussagy CU, Winterburn J, Santos-Ebinuma VC, Pereira JFB (2018) Production and extraction of carotenoids produced by microorganisms. Appl Microbiol Biotechnol 103:1095-1114. https://doi.org/ 10.1007/s00253-018-9557-5

Neofotis P, Huang A, Sury K, Chang W, Joseph F, Gabr A, Twary S, Qiu W, Holguin O, Polle JEW (2016) Characterization and classification of highly productive microalgae strains discovered for biofuel and bioproduct generation. Algal Res 15:164-178. https:// doi.org/10.1016/j.algal.2016.01.007

Novoveska L, Ros ME, Stanley MS, Pradelles R, Wasiolek V, Sassi J-F (2019) Microalgal carotenoids: a review of production, current markets, regulations, and future direction. Mar Drugs 17:640. https://doi.org/10.3390/md17110640

Ogbonna JC, Tanaka H (2000) Light requirement and photosynthetic cell cultivation-development of process for efficient light utilization in photobioreactors. J Appl Phycol 12:207-218. https://doi. org/10.1023/A:1008194627239

Ogbonna IO, Ogbonna JC (2015) Isolation of microalgae species from arid environments and evaluation of their potentials for biodiesel production. Afr J Biotechnol 14:1596-1604. https://doi.org/10. 5897/AJB2014.14327

Pal P, Chew JW, Yen H-W, Lim JW, Lam MK, Show PL (2019) Cultivation of oily microalgae for the production of third-generation biofuels. Sustainability 11:5424. https://doi.org/10.3390/su111 95424

Panahi Y, Khosroshahi AY, Sahebkar A, Heidari HR (2019) Impact of cultivation condition and media content on Chlorella vulgaris composition. Adv Pharm Bull. 9:182-194. https://doi.org/10. 15171/apb.2019.022

Pandey A, Gupta A, Sunny A, Kumar S, Srivastava S (2020) Multiobjective optimization of media components for improved algae biomass, fatty acid and starch biosynthesis from Scenedesmus sp. ASK22 using desirability function approach. Renew Energy 150:476-486. https://doi.org/10.1016/j.renene.2019.12.095

Powtongsook S, Nootong K (2019) Photoautotrophic cultivation of Chlorococcum humicola in stirred tank and airlift photobioreactors under different light settings and light supplying strategies for biomass and carotenoid production. J Chem Technol Biotechnol 94:3084-3092. https://doi.org/10.1002/jctb.6115

Pozzobon V, Lavasseur W, Guerin C, Gaveau-Vaillant N, Pointcheval M, Pere P (2020) Desmodesmus sp. pigment and FAME profiles under different illuminations and nitrogen status. Bioresour Technol 10:100409. https://doi.org/10.1016/j.biteb.2020.100409

Pribyl P, Pilny J, Cepak V, Kastanek P (2016) The role of light and nitrogen in growth and carotenoid accumulation in Scenedesmus sp. Algal Res 16:69-75. https://doi.org/10.1016/j.algal.2016.02. 028

Rausch T (1981) The estimation of micro-algal protein content and its meaning to the evaluation of algal biomass I. Comparison of methods for extracting protein. Hydrobiologia 78:237-251. https://doi.org/10.1007/BF00008520

Saitou N, Nei M (1987) The neighbor-joining method: A new method for reconstructing phylogenetic trees. Mol Biol Evol 4:406-425. https://doi.org/10.1093/oxfordjournals.molbev.a040454

Sathasivam R, Ki JS (2018) A review of the biological activities of microalgal carotenoids and their potential use in healthcare and cosmetic industries. Mar Drugs 16:1-31. https://doi.org/10.3390/ md16010026

Schüler L, Greque de Morais E, Trovão M, Machado A, Carvalho B, Carneiro M, Maia I, Soares M, Duarte P, Barros A, Pereira H, Silva J, Varela J (2020) Isolation and characterization of novel Chlorella vulgaris Mutants with low chlorophyll and improved protein contents for food applications. Front Bioeng Biotechnol 8:469. https://doi.org/10.3389/fbioe.2020.00469

Schulze PSC, Guerra R, Pereira H, Schuler LM, Varela JCS (2017) Flashing LEDs for microalgal production. Trends Biotechnol 35:1088-1101. https://doi.org/10.1016/j.tibtech.2017.07.011

Singh DP, Khattar JS, Rajput A, Chaudhary R, Singh R (2019) High production of carotenoids by the green microalga Asterarcys quadricellulare PUMCC 5.1.1 under optimized culture conditions. PLoS ONE 14:e02219930. https://doi.org/10.1371/journ al.pone. 0221930

Sui Y, Muys M, Van de Waal DB, D'Adamo S, Vermeir P, Fernandes TV, Vlaeminck SE (2019) Enhancement of co-production of nutritional protein and carotenoids in Dunaliella salina using a two-phase cultivation assisted by nitrogen level and light intensity. Bioresour Technol 287:121398. https://doi.org/10.1016/j.biortech. 2019.121398

Xie T, Xia Y, Zeng Y, Li X, Zhang Y (2017) Nitrate concentration-shift cultivation to enhance protein conten of heterotrophic microalga Chlorella vulgaris: Over-compensation strategy. Bioresour Technol 233:247-255

Yu X, Zhao P, He C, Li J, Tang X, Zhou J, Huang Z (2012) Isolation of a novel strain of Monoraphidium sp. and characterization of its potential application as biodiesel feedstock. Bioresour Technol 121:256-262. https://doi.org/10.1016/j.biortech.2012.07.002

Zhu L, Li S, Hu T (2019) Effects of nitrogen source heterogeneity on nutrient removal and biodiesel production of mono- and mix-cultured microalgae. Energy Convers Manag 201:112-114. https:// doi.org/10.1016/j.enconman.2019.112144

Zhuang L, Azimi Y, Yu D, Wu Y, Hu H (2018) Effects of nitrogen and phosphorus concentrations on the growth of microalgae Scenedesmus. LX1 in suspended-solid phase photobioreactors (ssPBR). Biomass Bioenerg 109:47-53. https://doi.org/10.1016/j.biombioe. 2017.12.017

Publisher's Note Springer Nature remains neutral with regard to jurisdictional claims in published maps and institutional affiliations. 